\title{
$\mathrm{SH}$ 化合物のカラゲニン浮腫増強作用 (V)
}

\author{
須田 浩・ 中田勝彦・高村俊史 ・ 山内秀泰・磯 正*
}

\author{
Potentiative effects of sulfhydryl compounds on carrageenan \\ induced edema in rats (V) \\ Hiroshi Suda • Katsuhiko Nakata • Toshifumi Komura • \\ Hideyasu Yamauchi - Tadashi Iso*
}

著者らはすでに, angiotensin converting enzyme (kininase II, EC 3, 4, 15, 1) 阻害剂である (4R)3-[(2S)-3-mercapto-2-methylpropanoyl] -4- thiazolidinecarboxylic acid (YS980) が，経口投与でラットの carrageenan（以下 Carr）浮腫を増強し，その浮腫増強に は炎症部位における kininase II 阻害作用が関与するこ とを報告1)した。

また kininogen 枯渴剤である bromelain (以下 Brm) は，静脈内投与により plasma kininogen level を低下 させるとともに，YS980 の浮腫増強作用をも抑制する

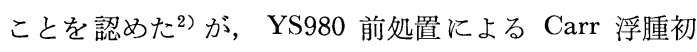
期の増強 (early phase の増強) と, YS980 後処置によ る Carr 浮腫後期の増強 (latter phase の増強) との間 には，Brm による抑制作用態度に差異がみられた。

すなわち, latter phase の増強は plasma kininogen level を反映するのに対して, early phase の増強の Brm による抑制は plasma kininogen level が正常に復した後 もさらに持続し，この抑制の prolongation には plasma kininogen 以外の factor の関与が推察された2).

今回, この early phase 増強の Brm による抑制と, tissue kininogen との関連を明らかにする目的で, Carr 浮腫に先行して Brm を足蹠皮下に投与し, 局所の tissue kininogen が枯渴したと考えられる状態において，YS 980 の Carr 浮腫増強作用を検討した.

\section{方 法}

Wistar 系雄性ラットを 1 群 6 匹用いた. Brm $0.1 \mathrm{mg} /$ paw, cellulose sulfate $0.1 \mathrm{mg} / \mathrm{paw}$, dextran $1 \mathrm{mg} / \mathrm{paw}$, compound $48 / 80 \quad 0.01 \mathrm{mg} / \mathrm{paw}$ あるいは histamine $0.2 \mathrm{mg} / \mathrm{paw}$ をラットの右後肢足蹠皮下に投与し, 浮腫 消退後 (histamine の場合は 6 時間後, ほかは 24 時間 後) に, 同じ部位あるいは反対側の左後肢足蹠皮下に

\footnotetext{
* Research Laboratory, Santen Pharmaceutical Co., Ltd. 参天製薬侏研究部
}

Carr $1 \mathrm{mg} / \mathrm{paw}$ を投与して浮腫を惹起した．YS980は $0.5 \%$ トラガント水溶液に懸濁して経口投与した. 足浮 腫は容積法にて測定し, plasma kininogen level は Diniz らの方法 ${ }^{3)}$ に準じて測定した.

\section{結 果}

図1に示すごとく, YS980 $1 \mathrm{mg} / \mathrm{kg}$ は Carr 起炎の 30 分前処置, あるいは 3 時間後処置のいずれによっても 速やかに浮腫を増強した。この増強作用は YS980 の投 与量が $0.01 \mathrm{mg} / \mathrm{kg}$ から $1 \mathrm{mg} / \mathrm{kg}$ の間で用量依存的で あり, $1 \mathrm{mg} / \mathrm{kg}$ で最大となった。

Brm は $0.1 \mathrm{mg} / \mathrm{paw}$ の右後肢足蹠皮下投与により， 図 2 に示すごとく起炎後 $0.5 \sim 1$ 時間をピークとする浮 腫を引き起こし，この浮腫は 24 時間後には消退した. YS980 $1 \mathrm{mg} / \mathrm{kg}$ は起炎 30 分前あるいは 3,9 時間後に 経口投与することにより Brm 浮腫を増強したが，24時 間後の浮腫消退時に投与しても増強作用は発現しなかっ た。な拈，Brm $1 \mathrm{mg} / \mathrm{paw}$ 足蹠皮下投与後 3 および 24 時 間後の plasma kininogen level はおのおの1.72 $1.79 \pm 0.24 \mu \mathrm{g} \mathrm{BKeq} / \mathrm{m} l$ plasma であり, 起炎剂の值 $1.9 \pm 0.10 \mu \mathrm{g} \mathrm{BKeq} / \mathrm{m} l$ plasma とくらべ有意な差は認 められなかった。

次に, Brm 浮腫消退後, 同じ部位に Carr $1 \mathrm{mg} / \mathrm{paw}$ を皮下注射して再度浮腫を若起し，YS980 $1 \mathrm{mg} / \mathrm{kg}$ に よる浮腫増強作用について検討したところ, 図 3 に示す ように early phase の増強は抑制されたが, latter phase の増強は抑制されなかった。

一方， Brm 非投与足である左後肢の Carr 浮腫にお いては, early phase および latter phase のいずれの増 強も抑制されなかった。 また cellulose sulfate 浮腫消退 後の Carr 浮腫においても，Brm の場合と同様の結果 が得られたが, kinin の関与がないとされる dextran 浮 腫, compound 48/80 浮腫あるいは histamine 浮腫消退 後の Carr 浮腫においては, YS980 の浮腫増強作用はま ったく抑制されなかった。

\section{考 察}

kininogen 枯渴剂である Brm を足蹠皮下に投与する ことにより浮腫が発現したが，この炎症には主として kininogen から遊離した kinin が関与するものと考えら 


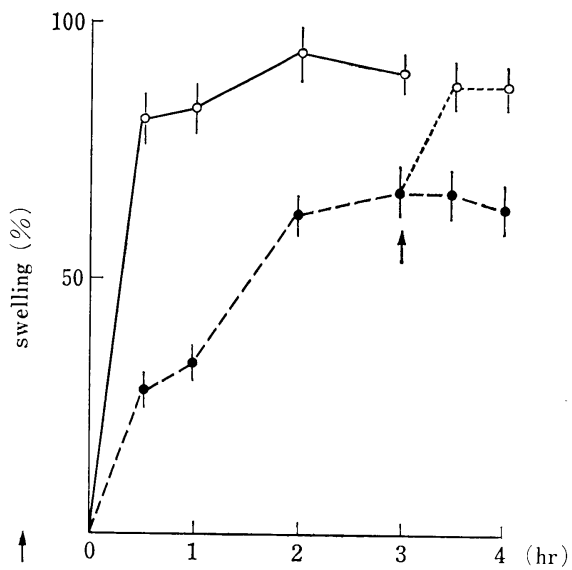

図 1 potentiative effect of YS980 on carrageenan induced paw edema in rats

: control, $\bigcirc$ : YS980, $1 \mathrm{mg} / \mathrm{kg}$, po $30 \mathrm{~min}$ before carrageenan injection, @ : YS980, 1 $\mathrm{mg} / \mathrm{kg}$ po $3 \mathrm{hr}$ after carrageenan injection

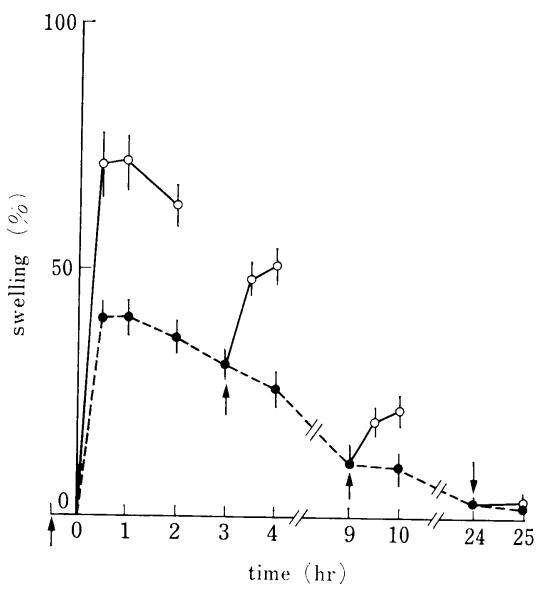

図 2 potentiative effect of YS980 on bromelain induced paw edema in rats

Bromelain ( $0.1 \mathrm{mg} / 0.1 \mathrm{ml}$ saline) was injected to the subplantar region of right hind paw. YS980 (1 mg/kg) was given orally $30 \mathrm{~min}$ before or $3 \mathrm{hr}, 9 \mathrm{hr}$ or $24 \mathrm{hr}$ after bromelain injection.

: control, $\bigcirc$ : YS980

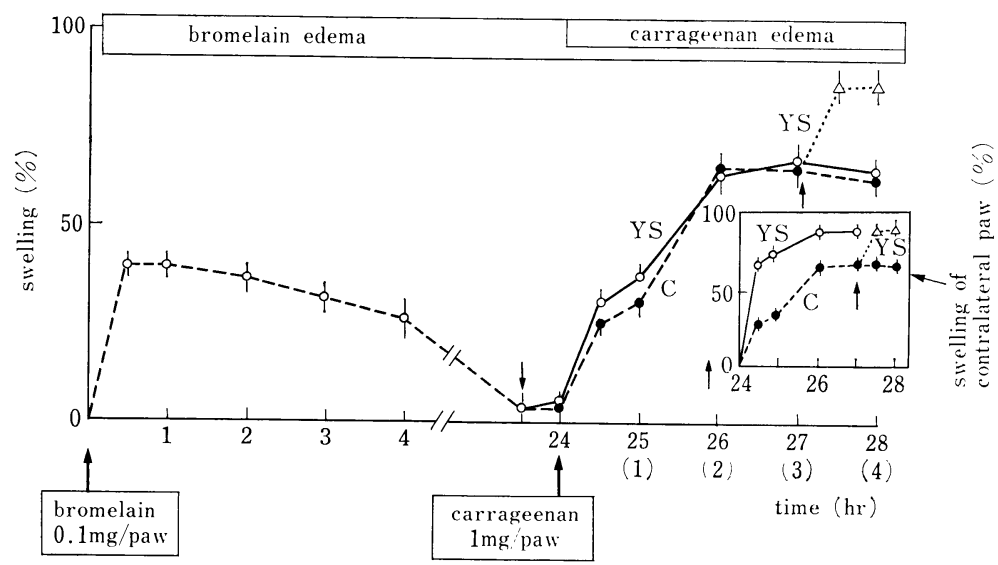

図 3 effects of bromelain and YS 980 on carrageenan induced paw edema in rats

YS980 ( $1 \mathrm{mg} / \mathrm{kg})$ was given orally $30 \mathrm{~min}$ before or $3 \mathrm{hr}$ after carrageenan injection.

れる. 事実, Brm 浮腫は converting enzyme 阻害剂, すなわち kininase II の阻害剂である YS980 によって 増強されたが，Brm 浮腫自体は起炎 24 時間後には消退 し，この時期には起炎部位の kininogen が枯渴した状態 にあると思われる。

したがって, Brm 浮腫消退後に惹起した Carr 浮腫に おいて，YS980による early phase の増強が認められ なかったことは, early phase の増強に tissue kininogen が関与していることを示唆するものと考えられる.

さらに, Brm 浮腫惹起後の plasma kininogen level に 変動のないこと, Brm 非投与足では Carr 浮腫増強が抑 制されなかったことから，この kininogen 枯渴状態は Brm 投与部位に限局したものであると考觉られる。す た, kinin の関与する浮腫のみが上記 early phase 増強 を抑制し，ほかの起炎刺激では抑制されなかったことか
ら，この抑制は炎症消退後の組織の反応性の低下など, 非特異的な原因に基づくものではないと考えられる.

以上より，YS980 による Carr 浮腫初期の増強には tissue kininogen の関与が示唆されたが, 組織中の kininogen 量を定量し, 今回の推定の裏づけを行うことが今 後の課題である。

\section{文 献}

1) Iso, T., Yamauchi, H., Suda, H., Nakajima, N., Nishimura, K., Iwao, J.: Experientia 34: 1202-1203, 1978.

2) Suda, H., Yamauchi, H., Iso, T.: J. Pharm. Pharmacol. 34: 60-61, 1982.

3) Diniz, C.R., Carvalho, I.F.: Ann. NY Acad. Sci. 104: 77-89, 1963. 